\begin{tabular}{c} 
OSOBA I MiŁOŚĆ \\
Filozofia Chrześcijańska $\bullet$ Tom 11, Poznań 2014 \\
Uniwersytet IM. Adama Mickiewicza w Poznaniu $\bullet$ Wydział Teologiczny \\
\hline
\end{tabular}

TADEUSZ KOBIERZYCKI

\title{
Od pojęć do zdarzeń i od zdarzeń do pojęć muzycznych. Spojrzenie filozofa procesu
}

(Rec.: Janusz Jusiak, Między zdarzeniem dźwiękowym a znaczeniem. Szkice z filozofii muzyki, Wyd. UMCS, Lublin 2013, ss. 339 [ISBN 978-83-7784-381-9])

Autor książki Janusz Jusiak z UMCS jest filozofem, zajmującym się metafilozofia, filozofią procesu A.N. Whiteheada, moralnością, metafizyką i kognitywistyką. Jego myślenie jest analityczne, semiologiczne, hermeneutyczne i historyczne. Jego styl pisarski, zdominowany strukturalnym słuchem na warstwę logiczną zdań, a wyraz stylistyczny oparty na elipsach, pozwala na wykrywanie logicznych ,sprzeczności.

J. Jusiak w swojej książce podjął próbę przedstawienia rozmaitych problemów poznawczych związanych z muzyką, przeglądając jej „definicje” w muzykologicznych wersjach, w deklaracjach muzyków, zwłaszcza kompozytorów, wykonawców, a także w dominujących opisach wybranych przedstawicieli filozofii europejskiej.

$\mathrm{Na}$ liście przytaczanych myślicieli, wspomagających analizę problemów muzycznych, jej aspektów ontologicznych i epistemologicznych, znajdują się: Arystoteles, Arystoksenos, Adorno, Augustyn, de Beauvoir, Bocheński, Boecjusz, Croce, Einstein, Forkel, Gilson, Hartmann, Heraklit, Hegel, Hume, Husserl, Ingarden, Jadacki, Kant, Kivy, Langer, Leibniz, Levinson, Lissa, Lotze, Marciszewski, Merlau-Ponty, Nagel, Nietzsche, Peirce, Penrose, Platon, Popper, Ricoeur, Russel, Sartre, Schlegel, Schopenhauer, Scruton, Stróżewski, Tatarkiewicz, Tomasz z Akwinu, Whitehead, Witwicki itd. Większość tekstów myślicieli z tej listy jest cytowana lub omawiana krytycznie bądź „,negatywnie”, gdy autor analizuje wypowiedzi odwołujące się do doktryn idealistycznych lub reistycznych, statycznych, totalistycznych, absolutystycznych, deterministycznych. Sam próbuje przeprowadzić wykład ukazujący muzykę jako rodzaj procesu, który rzeczy wprawia w ruch, a ruch wprowadza w rzeczy, które dzięki temu wibrują, drżą i dźwięczą.

Zestrojone lub rozstrojone atomy dźwiękowe prezentują się jako wiązki, zdarzenia, harmonie i dysharmonie, skale, melodie, zbiory akustyczne, figury, pola, obrazy, barwy i cienie, akcenty, rytmy i fale, struktury brzmieniowe, okrzyki i śpiewy itd., ewoluując w stronę tego, co muzyczne, w kontekście ciszy i szumów, stukotów, które są ich ramami, początkami i zakończeniami, brzegi narracji muzycznej, która wydobywa się z rzeczy ku umysłowi, czyniącemu z tego co rozbieżne - zbieżne, z rozproszenia ciągłość i spo- 
istość i na odwrót ze spoistego czyniącemu niespoiste, percypując te wytwory dźwiękowe na dwu poziomach, fizycznym, naturalnym oraz niefizycznym i nienaturalnym, poniżej percepcji muzycznej, na poziomie tej percepcji i ponad nią, i wokół niej, w sferze meta, epi, proto, co w języku łacińskim znakowane jest jako quasi-muzyczne.

W tym celu J. Jusiak wykorzystuje filozofię procesu, która unosi się nad tym napełnionym faktami muzycznymi filozoficznym tekstem, jak logos-wszystko - Heraklita. Jest to próba błyskotliwa, oryginalna, zbliżająca czytelnika do „ontologii zdarzeń”. I w końcu zbiera elementy muzyczne w całość - w muzyczny logos świata.

Drugą linię narracji esejów tworzą wypowiedzi kompozytorów. Na liście tej znaleźli się między innymi: Albeniz, Armstrong, Bach, Barenboim, Bartók, Beethoven, Berg, Berio, Berlioz, Bernstein, Boulez, Brahms, Brubeck, Busoni, Cage, Chopin, Copland, Coltrane, Czajkowski, Debussy, Dvořák, Ellington, Furtwaengler, Gardiner, Gershwin, Glass, Gottschalk, Haydn, Haendel, Harnoncourt, Hindemith, Horowitz, Ives, Jarret, Kirkby, Kodaly, Kostelanetz, Krauze, Kusewicki, Landowska, Ligetti, Lutosławski, Lully, Maderna, Mahler, Marsalis, Massenet, Mendelsshon, Messiaen, Milhaud, Monteverdi, Mozart, Możdżer, Musorgski, Olejniczak, Patkowski, Penderecki, Purcell, Ravel, Reger, Rimski-Korsakow, Satie, Schaeffer, Schoenberg, Schubert, Schumann, Skriabin, Solti, Stochausen, Stokowski, Strauss, Strawiński, Szostakowicz, Szymanowski, Teleman, Toscanini, Verdi, Vivaldi, Wagner, Walter, Webern, Xenakis itd.

Ich wypowiedzi, autodefinicje, impresje, założenia, przekonania, zamierzenia, osiągnięcia, wytwory, utwory, dzieła, realizacje i inspiracje stały się punktami zainteresowań filozofa, który słucha utworów, wypowiedzi o nich i konstruuje własne projekty ich objaśnienia. Dokonuje tego w ramach kategorii „zdarzeń muzycznych”, ich materialnego i niematerialnego podłoża, strukturalnych paraleli, nieciąłości czasowych i przestrzennych, fizycznych i afizycznych kształtów. Są one oparte na połączeniach wrażeniowych i na nieustannych próbach ich semantyzacji, które mają zamieniać wrażeniowe pola percepcji (łączyć impulsy aintelektualne, strefy asemantyczne, obiekty amorficzne i ich formy zamienione w znaki i symbole) w jasne pola znaczeniowe.

J. Jusiak, systemowo identyfikuje trudności w odpowiedzi na pytania: (1) czym jest muzyka jako muzyka?, (2) co sprawia, że dźwięki mogą mieć znaczenie?, (3) czym różnią się dźwięki mowy i dźwięki natury?, (4) jakie są kulturowe, literackie i malarskie konteksty muzyki? i (5) jaki jest związek wykonania utworu muzycznego i jego ontologii. Sporo miejsca zajmuje w szkicach J. Jusiaka zagadnienie powiązań muzyki z innymi dziedzinami sztuki, np. z plastyką, ale zastrzega, że ten związek nie może być przekonująco wyjaśniony poprzez wskazanie kategorialnie wyodrębnionego rodzaju czynności umysłowych, które mogłyby tłumaczyć naturę tego pokrewieństwa.

W rozdziale I, zatytułowanym: „Czym jest muzyka? (s. 13-97), autor bada kwestie muzyczne za pomocą takich kategorii jak - tajemniczość, ontologia (możliwość i przedmiot, istnienie dzieła i jego źródłowość) w jej rozmaitych ujęciach - idealizm i transcendentalizm, nominalizm i platonizm, substancjalizm, konceptualizm, intencjonalność, kontekstualność, kooperatywność, oraz tradycję muzyczną i granice swobody twórczej. Autor przedstawia też listę zagadnień, które są szczegółowo omawiane w pozostałych czterech rozdziałach.

Muzyka, zdaniem J. Jusiaka, znajduje się ,„po stronie przedmiotów w maksymalnym stopniu nieprzejrzystych dla spojrzeń czystej myśli” (s. 14). Zawdzięcza swoje istnienie 
ludzkiej świadomości, ale nie jest jej „produktem”. Świadomość nie obejmuje muzyki w pełni, ujmuje ją tylko aspektowo, podobnie jak przedmioty materialne, jest z tego pewna korzyść, że tak jak one ma charakter transcendentny, a nie tylko immanentny. Muzyka nie jest czymś tak materialnym, przestrzennym czy czasowym, jak przedmiot fizyczny (np. most czy budynek). One są wyraźnie usytuowane, mają swój wyraźny początek i koniec w czasie.

Podobne refleksje znajdujemy wcześniej u Sartre'a w tekście L'imaginaire. Psychologie phénoménologique de l'imagination (Paris 1940) - „Melodia muzyczna, na przykład, nie odsyła do niczego prócz siebie. Czyż katedra nie jest po prostu tą masą rzeczywistego kamienia dominująca nad okolicznymi dachami?" (J.P. Sartre, Wyobrażenie. Fenomenologiczna psychologia wyobraźni, tłum. P. Beylin, Warszawa 2012). Szkoda, że nie ma tu tego odniesienia i krótkiej dyskusji, żeby można było zrozumieć, jakie są różnice między obydwoma autorami.

Tekst J. Jusiaka jest nasycony refleksją metodologiczna, analizami semantycznymi, w kontekście ich relacji do świadomości traktowanej jako stała data ludzkiego poznania. Być może jest to najbardziej ugruntowane i dość optymistyczne przekonanie autora, że świadomość może być bezwzględnym kryterium odniesień porównań, analogii i falsyfikacji twierdzeń o muzyce. Czytelnik, który chciałby doszukać się w tym opracowaniu aprobaty dla kategorii „nieświadomości”, występującej we współczesnych analizach estetycznych, także muzyki, będzie zawiedziony. Wprawdzie pojawia się w indeksie nazwisko Z. Freuda, T.W. Adorna, ale chyba na nich wyczerpuje się limit dla tego typu analiz. Jest tak dlatego, że dominują tu obok kategorii świadomości, pojęcia uczuć, emocji i myślenia. Brak jest niemal zupełnie pojęcia wyobrażenia, tak rozumianego, jak choćby u J.P. Sartre'a, którego nazwisko pojawia się w książce w przypisie, przy okazji problemu „¿̇ycia autentycznego", obok nazwiska S. de Beauvoir.

Bardzo odważne i w Polsce nowatorskie są uwagi J. Jusiaka na temat możliwości ontologii muzyki, która to refleksja jest budowana w dialogu i sporze $\mathrm{z}$ fenomenologia, z dodatkiem hermeneutyki, którą autor traktuje dość życzliwie, promując np. analizę integralną czy kontekstualną, niżej oceniając możliwości analizy genetycznej, substancjalnej czy lingwistycznej. Nie jest też skłonny zadowolić się znaną w muzykologii analizą emotywistyczną (eksploatowaną do znudzenia w okresie barok-romantyzm). Autor odcina się też od naturalizmu i dyskretnie reklamuje teorię procesualną S. Reicha. J. Jusiak próbuje wskazać na kategorie „,całości” w muzyce, którą tworzą: „,warstwy”, ich „tło”, zdarzenia dźwiękowe i muzyczne, energia, emergencja, akcja, współdziałanie, koordynacja, dialog, improwizacja, znaczenie, intencja, przestrzeń, czas itp.

Niezwykle ciekawe i napisane w sposób brawurowy są małe paragrafy relacjonujące rozumienie muzyki przez idealizm obiektywny i transcendentalny (nieśmiertelny G.W.F Hegel, ale także A. Schopenhauer czy B. Croce, R.G. Collingwood czy dziś R. Scruton, ciekawe, że nie ma tu I. Kanta, por. np. badania K. Lipki, których autor nie wspomina). J. Jusiak odwołuje się do tych, którzy idą drogą Charles'a S. Peirce'a, autora rozróżnienia kategorii - typu i jego egzemplarzy. J. Jusiak obstaje przy opinii, że dzieło muzyczne to byt abstrakcyjny, i pojęcie abstrakcji w pierwszej części książki jest dość często używane.

Autor wyraźnie dystansuje się od wypowiedzi Platona (Ion, 533D-534D), że muzyka jest otrzymana od muz i jest niezniszczalnym wzorcem albo abstrakcyjną strukturą istniejącą odrębnie od świata materialnego w świecie czystych Form czy Idei. Ten skrajny re- 
alizm pojęciowy nie podoba się J. Jusiakowi, a także nie zadowala go idea partycypacji w bycie (jego Formach) lub koncepcja odbicia. Nie akceptuje Pitagorejskich idei opartych na ontologii liczenia i ontologii liczb (notabene podobnie postępowali indukcjoniści na Bliskim i Dalekim Wschodzie, a także współcześni fizycy). J. Jusiak chyba zbyt radykalnie odrzuca niektóre idee zawarte w Gorgiaszu, Państwie, Ionie, Fajdrosie i Fedonie, a także w tekstach współczesnych myślicieli takich jak P. Kivy, J. Dodds N. Wolterstroff, K.R. Popper i inni. Sugeruje, że platonicy chcą zatrzeć różnice między tworzeniem i odkrywaniem dzieła muzycznego. ,[...] platonizm stanowi nader wątpliwą próbę wyjaśnienia ontologicznej swoistości dzieła muzycznego" (s. 53).

Autor gniewa się na Poppera, że zmienia Schweitzerowskie rozumienie podziału twórców na obiektywnych i subiektywnych, dodając własny wątek i dylemat „wpływologiczny" do tej dyskusji, porównuje zmienne koleje losu (znaczenia) muzyki Bacha i Beethovena i ich znaczenie w różnych okresach dziejów kultury muzycznej.

W następnym paragrafie autor rozważa kwestię substancjalności formy muzycznej, odwołując się do Arystotelesa i jego teorii uniwersaliów, czyli przekonania, według którego byty muzyczne mogłyby istnieć podobnie jak substancje, lecz to jest chyba niemożliwe, gdyż nie istnieją w ten sam sposób jak przedmioty materialne czy stany mentalne, ale są nadbudowane nad substancjalnym tworzywem, np. na przeżyciach estetycznych w ich wydaniu aktowym. Nie spełniają tych założeń koncepcje osadzenia na substancji tworów muzycznych (por. np. E. Gilson czy E. Sourieau) i nie tylko.

Przy tej okazji J. Jusiak przypomina kategorię obiektów postrzeżeniowych (ang. perceptual objects) opisywanych w koncepcji M.C. Beardsleya. Przypomina też, że nie obowiązują analogie plastyczne, wizualne, fizyczne w odniesieniu do muzyki. I ten wątek, a nawet nastawienie antywizualistyczne wydaje mi się nieco przesadne w całej refleksji zawartej w tej książce, tym bardziej że malarstwo nie wyczerpuje tu wzorca analogii, a kwestią jest jego zbyt fizyczne czy też przestrzenno-fizyczne rozumienie. Uważam, że można mieć na ten temat inne, niż Albert Schweitzer, poglądy.

Autor martwi się tym, że Arystoteles nie próbował swojej metafizyki form substancjalnych zastosować do analizy muzycznej, ograniczając się do zagadnień etycznych i pedagogicznych w Polityce (ks. VII). Osobiście przypuszczałbym, że był synestetykiem i bardziej interesował się kategorią szumu czy szmeru kosmicznego (gr. psafos) niż dźwiękami, jak błędnie niekiedy tłumaczą to słowo, ku mojemu zaskoczeniu, polscy tłumacze tekstów Arystotelesa, nawet subtelny i genialny Paweł Siwek. J. Jusiak promuje tu tekst Arystotelesa Problemata („O problemach”), który wchodzi do zespołu pism logicznych, co jest pewną nowością w filozoficznej analizie muzyki w Polsce.

Z dużą życzliwością J. Jusiak przywołuje stanowisko Bogusława Schaeffera kompozytora i teoretyka muzyki, który uważał, że „muzyka to nie tylko zapis, ale także pewna idea, zawierająca się jakby między czy ponad dźwiękami, uzależniona co prawda od materialnej prezentacji dźwięków, ale przecież w gruncie rzeczy stojąca ponad nimi" (B. Schaeffer, Mały informator muzyki XX wieku, Kraków 1987, s. 110-111).

Skoro tak, to czy koniecznym warunkiem istnienia obiektu muzycznego musi być jego zapis i realizacja sensoryczno-brzmieniowa, chyba nie albo nie zawsze, bo stwierdza się nieprzystawalność realizacji do idei, co skłania kompozytorów do definiowania swojej twórczości muzycznej jako pewnego projektu konceptualnego, który nigdy nie da się zrealizować w sposób w pełni adekwatny w materii dźwiękowej, zawsze jednak jakiś frag- 
ment dzieła istnieje w pomyśle, projekcie, których fragmenty mogą nie być nigdy zrealizowane. Twórca, interpretator-wykonawca i słuchacz, w każdym z tych podmiotów muzyka istnieje inaczej, dociera w innej formie.

Teraz J. Jusiak wchodzi na drażliwe pole analizy polskiej tradycji estetycznej i filozoficznej w zakresie muzyki, zdominowanej przez ostatnie kilkadziesiąt lat przez celebrację fenomenologicznej koncepcji muzyki Romana Ingardena, co było formą ukrytego oporu i polemiki z analizami odwołującymi się do narzucanej instytucjonalnie ideologicznej analizy marksistowskiej, uprawianej w filozofii muzyki i muzykologii np. przez Zofię Lissę, czy nawet rodzajem subtelnej polemiki z teologiczną interpretacją, która miała i ma w Polsce wpływowych przedstawicieli, na różnych poziomach narracji. Głównym problemem jest pojęcie ,intencjonalności” wypromowane przez fenomenologów.

Przed laty Jacek J. Jadacki wymienił następujące problemy, które nastręcza fenomenologiczna koncepcja dzieła muzycznego R. Ingardena: (1) niepewność co do istnienia przedmiotów intencjonalnych, (2) niemożność odróżniania ich od ich zawartości, (3) hipostazowanie przedmiotów intencjonalnych, (4) zbytnie deprecjonowanie psychologistycznej teorii muzyki.

Po latach niepełna lista zarzutów została przez J. Jusiaka sprowadzona do 10 punktów, które są problematyczne. Są nimi: (1) dogmatyczna teza o jednowarstwowej strukturze dzieła muzycznego (C. Dalhaus), (2) zacieranie sensu muzycznego i sensu językowego (C. Dalhaus), (3) umniejszanie znaczenia improwizacji i dialogu w muzyce (B.E. Benson), (4) pomijanie muzyki aleatorycznej, elektronowej, konkretnej, ludowej czy pozaeuropejskiej (Z. Lissa), (5) brak jasnych kryteriów różnicujących zapis nutowy od dzieła muzycznego i jego wykonania (A. Pytlak i J.J. Jadacki), (6) umniejszanie autonomii w sztuce (B. Schaeffer), (7) wadliwe thumaczenie muzyki absolutnej (M. Wysocki), (8) zaprzeczanie możliwości poznania dzieła muzycznego bez pośrednictwa wykonania (M. Wysocki), (9) brak wyraźnych argumentów, że przedmioty „,czysto intencjonalne” istnieją (M. Rosiak), (10) ograniczona przydatność kategorii tożsamości dzieła muzycznego w teorii i filozofii muzyki (J. Jusiak).

Jak wiadomo, problem tożsamości dzieła muzycznego Ingarden sformułował w 1928 roku i później już go nie rewidował ani nie modyfikował. Listę zarzutów odnośnie do fenomenologii muzycznej można by znacznie wydłużyć, na przykład o rozumienie miejsc niedookreślonych, które należałoby połączyć z teorią o projekcji czy identyfikacji projekcyjnej, znanej choćby z psychoanalizy prawie nieobecnej w polskiej analizie muzycznej.

Niezwykle interesująco zapowiada się podrozdział zatytułowany kontekstualno-kooperatywny wymiar muzyki, tym bardziej że pojęcie to nie jest bardzo obecne w analizie muzyki, choć wielu autorów takich analiz nie wie o tym, że je stosuje, tak jak pan Jourdain nie wiedział, że mówi prozą. Pragmatyczny i ekstensjonalny (estetyczny) aspekt muzyki uzupełniaja jej aspekt językowy (intensjonalny - por. J. Świdziński), ale J. Jusiak próbuje nadać mu nieco inne znaczenie.

Autor wielokrotnie posługuje się kategorią idealizmu, nominalizmu i konceptualizmu i martwi się, czy są to kategorie właściwe do analizy w zakresie filozofii muzyki, zastanawia się, czy konceptualizm poradziłby sobie z określeniem, czy zbiór dźwięków w krótkim utworze trwającym np. 4,5 minuty to jeszcze muzyka czy nie, podobnie jak stos przypadkowo ułożonych kamienie (cegieł) jest już rzeźbą czy nie.

Wspominam o tym, gdyż autor odwołuje się do autorytetu Arnolda Schoenberga, który o dokonaniach swojego młodszego i kolegi i ucznia Johna Cage'a, który zdemonto- 
wał klasyczne definicje muzyki i jej rozumienie, powiedział, że „nie jest on kompozytorem, ale wynalazcą". To zdanie jest prawdziwe tylko wtedy, gdy rozumie się muzykę jako przedmiot skomponowany z dźwięków posegregowanych według systemu dur-moll, ale nie jest prawdziwe, gdy tradycyjnie rozumiane komponowanie definiuje się jako swobodne „organizowanie dźwięków”.

Duży fragment rozważań J. Jusiak poświęca problemowi autorstwa kompozytorów w XVIII wieku, gdy nagle pojawia się problem zapożyczeń, cytatów, kopii przeróbek, wersji, np. u Bacha, Haendla, Haydna, Mozarta czy Beethovena itp. Przyczyną tych praktyk był zwyczaj, zabawa, rywalizacja, wygodnictwo, złośliwość, ale i fascynacja jakimiś fragmentami cudzych dzieł muzycznych i próba ich „poprawiania”, tworzenie autocytatów dla zrobienia czegoś lepiej, a nie inaczej (por. A. Einstein o Haendlu) itp. Jaki jest status ontyczny tych wytworów muzycznych, podobnie jak wytworów innych dziedzin sztuki, trudno określić, raczej trzeba by tu przenieść problem z ontologii do epistemologii.

Podobne problemy stwarza zagadnienie wykonania utworów muzycznych. Jest ono tu tak ważne, że autor poświęca mu już drugi rozdział (ontologia wykonania, struktura dźwiękowa wykonania, instrumentacja wykonania). Uważam, że nie jest to problem ontologiczny, ale epistemologiczny. Skłonność do ontologizacji pojęć określających jakieś formy muzyczne jest chyba zbyt mało krytycznie przedstawiona w książce J. Jusiaka. Dlatego ważne jest zdanie: „Dźwięki ciążą ku ciszy podobnie jak przedmioty materialne ku ziemi, ale i cisza ciąży ku dźwiękom" (s. 129). Niestety, jest to tylko mały, choć genialny wgląd w zagadnienie ontologii muzyki współczesnej.

Skłonność ontologiczna jest zrównoważona przez skłonność semiotyczną autora, gdy zadaje pytanie, co sprawia, że dźwięki mogą mieć znaczenie. Otwiera ono tak szeroki teren analizy, że nie sposób go tu streścić. Potem czytelnik może się dowiedzieć, czym są tytułowe „zdarzenia dźwiękowe”. Dźwięk nie jest więc tylko jakością zmysłową, ale właśnie zdarzeniem, mającym swój odpowiednik fizykalny i mierzalny. To jest też świadomy lub nieświadomy fragment świetnej analizy reistycznej dźwięku, ale w ujęciu filozofii procesu. Nakładanie się na siebie zdarzeń dźwiękowych przedstawione jest na przykładzie II Symfonii (1966/1967) Witolda Lutosławskiego.

Muzyka, zdaniem J. Jusiaka, to nakładanie się na siebie „zdarzeń dźwiękowych”, a nie po prostu dźwięków.

Potem mowa jest o formie dzieła muzycznego, przestrzenności, rozciagłości, wiązki, linii melodycznych itp. To prowadzi autora do pytania, kiedy zdarzenia dźwiękowe coś znaczą. Autor dokonuje krytyki redukcjonistycznego podejścia do zagadnienia znaczenia muzycznego. Ma rację, że same atomistycznie traktowane szumy lasu czy dźwięki dzwonów albo śpiew słowika muzyki nie tworzą, bo nie ma w tych zdarzeniach wzorca całości dźwiękowej, chyba że przyjęłoby się, iż taką całością jest cisza/dźwięku i dźwięk/ciszy, cisza jako składnik dźwięku, którego nie słychać, ale J. Jusiak nie uwzględnia tu takiej możliwości. Być może dlatego, że zbytnio zawierzył stanowisku Leonarda B. Meyera, a odmienne stanowisko Messiaena J. Jusiak chciałby potraktować jako swoisty ewenement $\mathrm{w}$ dziejach europejskiej muzyki.

Muzyka - jak przyznaje J. Jusiak - jest nie tyle sprawą techniki układania w estetyczne wzory dźwięków, ile jest przede wszystkim problemem syntaktycznym, który ma dźwięki usensowniać, co bardzo często jest pomijane lub marginalizowane np. w XIX-wiecznej analizie muzycznej. Dlatego nie brak na liście autora rozprawy z „logiki mu- 
zycznej" Forkela (1788), który pojawia się na kartach tego studium obok C. Dalhausa. Podjęli oni próby oparcia analizy muzycznej na przesłankach logicznych, a nie tylko akustycznych, fizycznych, emotywistycznych, somatycznych albo estetycznych.

W kolejnym rozdziale, który przedstawia problem mowy dźwięków i natury, dla kontrastu autor zaczyna od wypowiedzi Charles'a Ivesa o tym, że muzyka to język transcendentalny o dalekim zasięgu. Musiał to podkreślić, ponieważ w USA w popularnej filozofii i psychologii transcendencję rozumie się jako zwykłe przekroczenie jakiejś granicy fizycznej, np. dotknięcie ręką ściany to transcendencja, pocałunek to transcendencja, bieg to transcendencja. Nie trzeba tu żadnej medytacji czy modlitwy do jakiegoś wyobrażonego obiektu (Ducha czy Boga itp.).

To rozumienie jest oparte na pragmatyzmie, a nie na spirytualizmie, jak w Europie, w tym sensie język transcendentalny niczym nie różni się od zwykłego języka, tu chodzi raczej o odłączenie zdarzenia od znaczenia, na co zwrócił uwagę w Europie Paul Ricœur. $\mathrm{W}$ takim pragmatycznym sensie język muzyki nie różni się wiele od języka werbalnego (wymowy i pisma). Tu znakomity cytat z F. Chopina „Dźwięk oderwany nie czyni muzyki, tak jak słowo nie czyni języka. Aby powstała muzyka potrzeba wielu dźwięków" (F. Chopin, Szkice do metody fortepianowej, tłum. Z. Skowron, Kraków 1995, s. 47).

Wyraźną sympatią intelektualną, która modeluje rozumowanie muzyczne J. Jusiaka, darzy on twórczość muzyczną Charles'a Ives'a, który próbował tonalizmu i atonalizmu, ale zastanawiał się też nad rolą natchnienia, inspiracji, uniesienia, emocjonalnego podniecenia, instynktownych uczuć, mglistych intuicji, introspekcyjnych doznań, subiektywnych i obiektywnych źródeł, po czym pyta: „Co się za tym kryje? «Głos Boga», powiada artysta, «Głos szatana» mówi słuchacz z pierwszego rzędu" (Ch. Ives, Eseje przed Sonata, thum. P. Graff, „Res Facta” 1971, nr 5, s. 80).

Wolałbym, żeby w miejsce Boga i Szatana pojawiło się u Ives’a pojęcie Jaźni (podobnie jak u C.G. Junga) jako źródła muzyki. Wtedy znika też dualizm subiektywne-obiektywne i nieprzeparta potrzeba nominalizmu w próbie połączenia sprzecznych argumentów w jakimś jednym zjawisku, które wszystko tłumaczy albo unieważnia. W tym przypadku jest to pojęcie „niewykonalności” (s. 215).

Teraz dowiadujemy się, że zdarzenia dźwiękowe mają zdolności quasi-semantyczne i że tkwią one w „naturze rzeczy”, że są trudne od razu do uświadomienia. Autor twierdzi, że dźwięki natury nie są zdolne „do mowy”, bo nie mają źródeł podmiotowych, jeśli przez mowę rozumieć zdolność umysłu do przekazywania innym podmiotom poznania uściślonych w pojęciach znaczeń słów czy nazw ogólnych. Nie tworzą one bytów zorganizowanych immanentnie i nie dają się zdefiniować niezależnie od kontekstu myślowego, w jakim są ujmowane (s. 219).

Wszelkie trudności z filozoficzną analizą muzyki J. Jusiak chce wytłumaczyć za pomocą pojęcia kontekstu, który wydaje mi się rozumiany w książce zbyt deterministycznie i absolutystycznie potraktowany chyba dlatego, że autor nie zdecydował się, co będzie grało rolę podmiotu w jego analizach ja, jaźń czy świadomość i umysł, który nie jest tylko maszyną reaktywną. „Mowa dźwięków” jest określeniem zastępczym, które mogłoby przysługiwać mowie podmiotu.

Jak wiadomo, Anton Webern (A. Webern, Droga do Nowej Muzyki, Kraków 1972, s. 17-18), wzorując się na ujęciu J.W. Goethego Farbenlehre, używa wyrażenia „myślenie muzyczne", a konkurent Schoenberga I. Strawiński stwierdza, że zjawisko muzyki jest 
formą rozmyślania w kategoriach dźwięku i czasu (I. Strawiński, Poetics of Music, Cambridge 1947, s. 16). J. Jusiak uważa, że „Dźwięk to amorficzny fenomen słuchowy, ale i abstrakcja, obiektywny byt, objawiający swe działanie poprzez gotowość do samoistnego komponowania się, wchodzenia w związki i zestrojenia, które swoje potencjalne znaczenie uzyskują same $\mathrm{z}$ siebie, $\mathrm{z}$ rozpoznawalnych $\mathrm{w}$ samym materiale dźwiękowym sposobów sensownego łączenia poszczególnych tonów i ich nagromadzeń” (s. 220).

Niezwykle przekonujące i piękne są studia nad ,muzyką przyrody”, opisywaną przez L. Staffa, Thomasa S. Eliota. Cała mitologia literacka albo etologiczna ,śpiewu” słowika, kukułki, sowy, całego świata zwierząt i roślin ma pokazać prefigurację ewolucyjną ludzkiego głosu i śpiewu, który pierwotnie także pełnił funkcję komunikacji bezpośredniej w społeczeństwach pierwotnych, a teraz znamy ją w „wyższej formie” intencjonalnych wykonań rzekomo bezinteresownych. Takie myślenie mógł z dobrodziejstwem swojego kompozytorskiego ptasiego inwentarza promować chyba tylko Olivier Messiaen. Następnie analizowane są ,głosy instrumentów” i „głosy przedmiotów”.

Chodzi tu o rozszerzenie katalogu animacji dźwiękowej z nagrań elektronicznych, z taśmy magnetofonowej, aparaturowych, technicznych lub o rozszerzanie palety brzmieniowej tradycyjnych instrumentów (np. fortepian preparowany) czy wykorzystanie fragmentów instrumentów poza dotychczasowymi sposobami dotykania klawiatury lub otworów fonicznych, poprzez pukanie, pocieranie itp. Pewną nowością było też inne pojmowanie tego, co naturalne (symbolizm, transcendentyzm, abstrakcjonizm), na przykład w ujęciu Weberna, Messiaena, Bouleza czy Ives’a.

Znów pojawia się w rozprawie J. Jusiaka motyw: (1) muzyki duszy (Platon, Leibniz), (2) głosu (Arystoteles, Schopenhauer), (3) melodii (Helmholtz, Wagner, Skriabin), (4) dźwięku (Heraklit, Debussy, Messiaen, Bartok, Stockausen, Mache, Ives, Emerson, Thoreau, bracia Cowell czy Patkowski). Jednak najważniejsza dla całej pracy J. Jusiaka wydaje się reistyczna sentencja, że „Muzyka nie zapisuje rzeczy, ale sposób, w jaki rzeczy się wydarzają. Zdarzenia nie przesuwają się przed nami samotnie, w izolacji, ale niosą z sobą wspomnienia i zapowiedzi, zderzając się i ścierając także z innymi zdarzeniami” (por. H. i S. Cowell, Ives, Kraków 1982, s. 12).

Wiele problemów, które formułuje, odkrywa i interpretuje J. Jusiak, ma źródła nie tylko u Pitagorasa, Platona, Arystotelesa czy św. Augustyna, a także w pominiętym traktacie Boecjusza, który wyróżnia - „artystów fizycznych” obok ,artystów właściwych”. Jedni muzycy zajmują się grą na instrumentach, są odlegli od wnikliwego wejrzenia w naukę (np. cytrzyści czy organiści), drudzy komponuja pieśni, jako kompozytorzy bardziej wykorzystują ,naturalny instynkt” niż badania naukowe, trzecia grupa muzyków zajmuje się oceną osiągnięć instrumentalnych i kompozycji pieśni, analizując i oceniając rytm, melodie i całą kompozycję - „Ta klasa, jako jedyna przynależy właściwie do muzyki, bowiem całkowicie zajmuje się badaniem naukowym" (Boecjusz, De Institutione Musica tłum. D. Burakowski 2008, s. 218).

Boecjusz na koniec stwierdza: „Muzykiem jest przeto ten, kto posiada umiejętności zgodnie z badaniami naukowymi i zasadami muzyki; o rodzaju dźwięku i rytmie, o skalach i ich mieszaniu, o kompozycji pieśni, krótko mówiąc, oceny tego wszystkiego, co będziemy później rozwijać" (Boecjusz, op. cit., 2008, s. 218). Szkoda, że trop Boecjański jest słabo obecny w znakomitym dziele J. Jusiaka, cały trop Pitagorejskiej ontologii, która jest nadal aktualna, ale mało obecna w polskiej filozofii muzyki. 
Autor rzetelnie ukazuje, że element heurystyczny pojawia się we wszystkich etapach formowania muzycznych treści, które mają charakter quasi-językowy. Jest przekonany, że specyfikę dzieła muzycznego trzeba analizować w kategoriach myślenia kontekstualnego. Dla filozofów interesująca jest zastosowana tu metoda analityczna, dla muzyków metoda asocjacjonistyczna, obie zachowane w odpowiednich proporcjach. Muzyka, która w naturze brzmi lub milczy, w tym tekście znajduje swoje pojęcia $\mathrm{w}$ wielu wymiarach filozoficznej myśli. 